\title{
Laser photoresection in the preoperative assessment of a bronchial adenoma
}

\author{
P R W STANLEY, T ANDERSON, K M PAGLIERO \\ From the Royal Devon and Exeter Hospital (Wonford), Exeter
}

\begin{abstract}
Preoperative laser photoresection of a bronchial adenoma allowed more accurate evaluation and better planning of the operative procedure.
\end{abstract}

Treatment with the neodynium-yttrium-garnet laser $(\mathrm{Nd}$ YAG laser) is a well established method for resection of tumour obstructing airways. ${ }^{1-10}$ As the treatment is potentially dangerous, it was introduced cautiously and reserved for palliation of distressing symptoms in patients dying of carcinoma of the bronchus unresponsive to other forms of treatment. ${ }^{1-9}$

The initial success of the method allows extension of the indications for treatment of bronchial malignancy to include patients with less advanced disease, and to combine it with other treatments. ${ }^{7-10}$ It has been suggested that preoperative laser photoresection as part of the preparation for majory surgery might benefit certain patients. ${ }^{6}$

Address for reprint requests: Mr P R W Stanley, Department of Thoracic Surgery, Royal Devon and Exeter Hospital (Wonford), Exeter EX2 5DW.

Accepted 5 May 1988

\section{Case report}

A 66 year old woman presented with a five month history of cough with haemoptysis. She had complained of a wheeze in the upper right chest, aggravated by lying on her right side, for 10 years and had been prescribed bronchodilators with little benefit. An episode of haemoptysis 10 years before this admission was ignored. There was no other important past medical history and she was a non-smoker. Examination confirmed the wheeze over the right chest, but no other abnormality. Vital capacity, $\mathrm{FEV}_{1}$ and peak flow were all about $80 \%$ of her predicted values.

Fibreoptic bronchoscopy showed a plum coloured tumour practically occluding the right main bronchus (figure, A). It was impossible to negotiate the bronchoscope past the tumour to determine its exact anatomy. Biopsy confirmed a bronchial adenoma of the carcinoma type. Resection was recommended but, as the anatomy was unknown, we undertook laser photoresection with a view to proceeding to surgery. At photoresection the tumour was found to have a pedicle on the lateral wall of the right main bronchus, some $0.5 \mathrm{~cm}$ above the origin of the right upper lobe bronchus.

It was then planned to remove the tumour completely by sleeve resection of the right main bronchus, without sacrificing any lung tissue. At thoracotomy a wedge resection of the
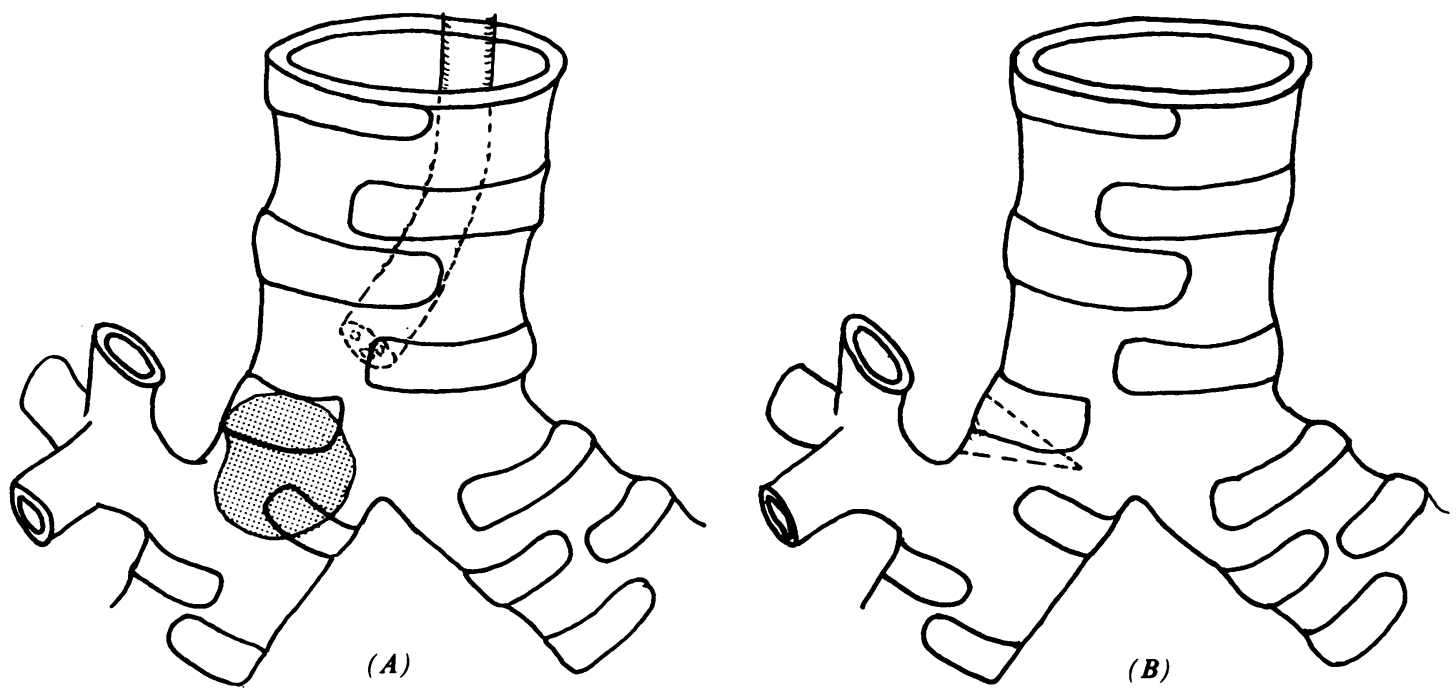

(A) Anatomy of the bronchial adenoma (left, hatched area) and (B) the line of resection (right, dotted lines). 
bronchial wall was performed. (figure, B). An immediate frozen section confirmed that the cut edges were free of tumour, so the bronchus was closed with interrupted polyglycolic acid (Dexon) sutures, reinforced with a pedicled pleural flap. The patient made an excellent recovery and has had no further haemoptysis, cough, wheeze, or breathlessness.

\section{Discussion}

Bronchial adenomas are known to enlarge within the bronchial lumen, so that the visible proximal lesion may not show the anatomical origin of the lesion. In this patient the adenoma presented as a large tumour obstructing the right main bronchus. At bronchoscopy we were unable to establish thu origin of the lesion and therefore unable to find the most conservative anatomical approach to excision of the lesion.

Endoscopic removal of the intraluminal bulk of the tumour is not an alternative to complete excision, but it allowed us to establish with little doubt the extent of the tumour in the bronchus, although the exact extent of submucosal spread could be established only by histological examination of the frozen section. In addition, restoration of airway patency may be welcome in the preoperative preparation of a patient with severe airways obstruction from the lesion. ${ }^{6}$ The advantage of laser treatment for piecemeal removal is the reduced risk of haemorrhage. Apart from the obvious risk to the patient, the absence of blood obscuring the operative field allowed us to define the pedicle of the adenoma easily. Preoperative treatment of this tumour with laser photoresection allowed us to place our bronchotomy more accurately and so remove the smallest amount of lung tissue at thoracotomy. Histological examination of a frozen section was helpful in excluding submucosal infiltration at the cut edge of the bronchus. This approach could also be used in the preoperative assessment of some cases of bronchogenic carcinoma.

We thank Miss E Simmonds for the illustrations.

\section{References}

1 Personne C, Colchen A, Leroy M, Vourc'h G, Toty L. Indication and technique for endoscopic laser resections in bronchology? Thorac Cardiovasc Surg 1986;91:710-5.

2 Hetzel MR, Nixon C, Edmonstone WM, et al. Laser therapy in $1 \overrightarrow{\overrightarrow{\theta \theta}}$ tracheobronchial tumours. Thorax 1985;40:341-5.

3 Parr GVS, Unger M, Trout RG, Atkinson WG. One hundref neodynium-YAG laser ablations of obstructing tracheal neoplasms. Ann Thorac Surg 1984;38:374-81.

4 Kvale PA, Eichenhorn MS, Radke JR, Miks V. YAG lasey photoresection of lesions obstructing the central airways. Chest 1985;87:283-8.

5 Dumon JF, Merick B, Surpas P, Ragni J. Endoscopic resection $\overrightarrow{\text { in }}$ bronchology using the YAG laser-evaluation of a 5 yeat experience. Schweiz Med Wochenschr 1985;115:1336-44.

6 George PJM, Garrett CPO, Goldstraw P, Hetzel MF? Ramsay AD. Resuscitative laser photoresection of a trachees tumour before elective surgery. Thorax 1986;41:812-3.

7 Joyner LR Jr, Maran AG, Sarama R, Yakaboski A. Neodyniü YAG laser treatment of intrabronchial lesions-a new mappiog technique via a flexible fibreoptic bronchoscope. Chest 1985 87:418-27.

8 Eichenhorn MS, Kvale PA, Miks VM, Seydel HG, Horowitz Radke JR. Initial combination therapy with YAG laser photoresection and irradiation for inoperable non-small cell carcinoma of the lung. Chest 1986;89:783-5.

9 Macha HN, Koch K, Stadler M, Schumacher W, Krumhaar New technique for treating occlusive and stenosing tumours the trachea and main bronchi: endobronchial irradiation high dose iridium-192 combined with laser canalisation. Thor 1987; 42:511-5.

10 Guerin JC, Riou R, Greck E, Martinat Y, Champel F. Resection of bronchial carcinoid tumour with the YAG-Nd laser undet local anaesthesia. Rev Pneumol Clin 1986;42:49-52. 